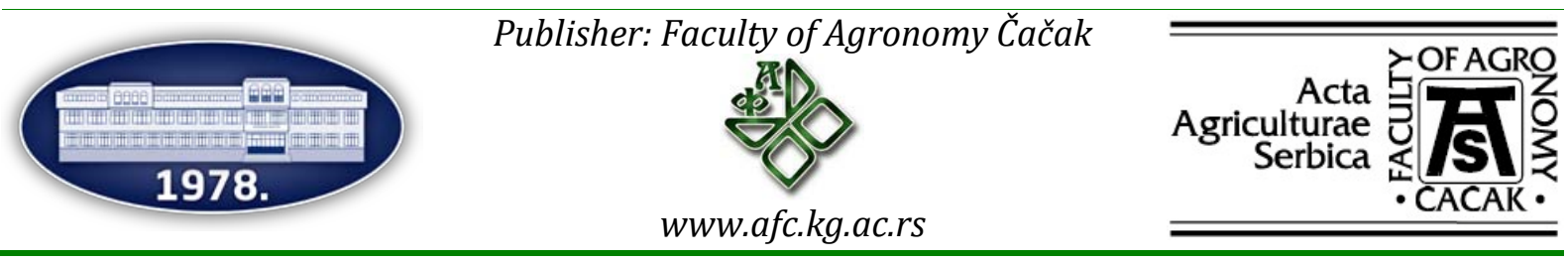

\title{
Cleaning and disinfection procedures in the dairy industry during COVID-19
}

\author{
Slavica Vesković Moračanin ${ }^{*}$, Saša Džonlaga², Nurgin Memiši², \\ Dragutin Đukic ${ }^{3}$, Zoran Ostojić ${ }^{4}$ \\ ${ }^{1}$ Institute for Meat Hygiene and Technology, Kaćanskog 13, Belgrade, Serbia \\ ${ }^{2}$ AD Imlek - Subotica, Tolminska 10, Subotica, Serbia \\ ${ }^{3}$ Faculty of Agronomy Čačak, University of Kragujevac, Cara Dušana 34, Čačak, Serbia \\ ${ }^{4}$ Union Nikola Tesla University, Cara Dušana 62-64, Belgrade, Serbia
}

*Corresponding author: slavica.veskovic@inmes.rs

Received 16 May 2020; Accepted 25 May 2020

\begin{abstract}
A B S T R A C T
The pandemic caused by the coronavirus (SARS-CoV-2) spread to Serbia in March 2020, causing a large-scale outbreak of infection in humans and more than 200 human deaths in two months. Although data on the epidemiology, virology, clinical features, treatment and prevention of this severe respiratory syndrome (COVID-19) are still incomplete, it is certain that the main mode of transmission of the virus is from person to person, through respiratory droplets as the primary transmission route. To date, the World Health Organization has no evidence to suggest that the virus can be transmitted through food, but human infection due to direct contact with contaminated surfaces, tools, equipment and other objects cannot be excluded. The application of good hygiene and manufacturing practices is the most important control measure against this causative agent, primarily involving appropriate employee protection, continuous monitoring of movement and entry restrictions for people and means of transport, and proper targeted sanitation. The choice and use of disinfectants, mostly peroxide, ethanol and hypochlorite based compounds, ensure proper protection of people and an undisturbed production cycle in the food industry in general, and in the dairy industry in particular.
\end{abstract}

Keywords: coronavirus, disinfection, prevention measures, milk industry.

\section{И 3 В О Д}

Пандемија изазвана коронавиросом (SARS-CoV-2) проширила се Србијом у марту 2020. године, проузрокујући велико избијање инфекције код људи и више од 200 смртних случајева за два месеца. Иако су подаци о епидемиологији, вирусологији, клиничким карактеристикама, лечењу и превенцији овог тешког респираторног синдрома (COVID-19) још увек непотпуни, сигурно је да је главни начин преношења вируса од особе до особе, путем респираторних капљица као примарни преносни пут. До данас Светска здравствена организација нема доказа који указују на то да се вирус може пренети храном, али заражавање људи услед директног контакта са контаминираним површинама, алатима, опремом и другим предметима не може се искључити. Примена добре хигијенске и производне праксе најважнија је контролна мера против овог вируса, која пре свега укључује одговарајућу заштиту запослених, континуирано надгледање ограничења кретања и уласка људи и превозних средстава и одговарајућу циљану санитацију. Избор и употреба средстава за дезинфекцију, углавном једињења на бази пероксида, етанола и хипохлорита, обезбеђују одговарајућу заштиту људи и несметан производни циклус у прехрамбеној индустрији уопште, а посебно у млекарској индустрији.

Кључне речи: коронавирус, дезинфекција, превенција, мере, млечна индустрија.

\section{Introduction}

In early December 2019, in Wuhan, the capital of China's Hubei province, the first death from pneumonia of unknown cause was recorded (Huang et al., 2020). Shortly afterwards, Chinese scientists isolated a pathogen which was first identified as a new RNA betacoronavirus 2 (SARS-CoV-2) similar to SARS-CoV (Zhu et al., 2020). SARS-CoV-2 (genus: Betacoronavirus) belongs to the family of Coronaviridae, a large family of enveloped, positivesense single-stranded RNA viruses. The structure of the receptor-binding gene region is very similar to that of the SARS coronavirus, and the virus has been shown to use the same receptor, the angiotensin-converting enzyme 2 (ACE2), for cell entry (Zhou et al., 2020).

The Coronavirus Study Group of the International Committee on Taxonomy of Viruses has proposed that this virus be designated severe acute respiratory syndrome coronavirus 2 (SARS-CoV-2) (Gorbalenya et al., 2020). This severe acute respiratory syndrome has been named COVID-19 by the World Health Organization (WHO, 2020) after the etiology of the causative agent itself (SARS-CoV-2, Coronavirus Disease) and the year it first occurred (2019).

Today, COVID-19 has the character of a pandemic i.e. a disease internationally important for the human population. Cases have been reported on all continents, 
except Antarctica, and have been steadily rising around the world. As of early May 2020, 214 countries were affected by the virus, with over 3.5 billion people worldwide ill with the virus, and more than 250.000 deaths (Figure 1). Updated case counts can be found on the World Health Organization (WHO) and European Center for Disease Prevention and Control websites (ECDC).

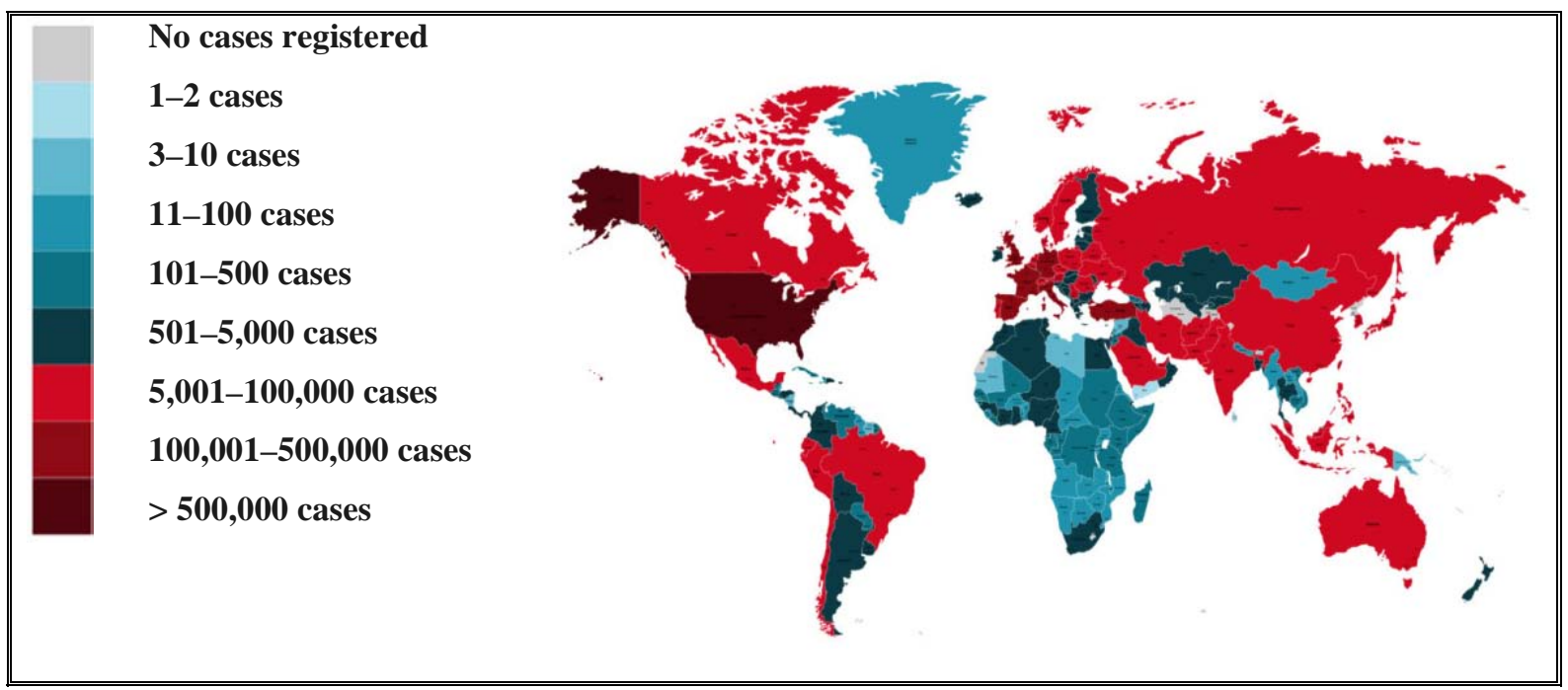

Figure 1. Coronavirus disease, COVID-19 (Source: https://covid19.rs/)

The first case of COVID-19 in the Republic of Serbia was recorded on 6 March 2020. As in other countries, the occurrence of this virus was a completely new experience and the virus was previously unknown to Serbian epidemiologists, other medical experts and the entire country. The situation led to the state of emergency and over 200 human lives lost (https://covid19.rs/). However, regardless of these facts, the food industry and primary agricultural production in the country did not cease their production activities, but they had to adapt their work under the new circumstances to the pandemic situation.

\section{Transmission of the virus}

Although data on the epidemiology, virology, clinical features, treatment and prevention of COVID-19 are still incomplete, it is certain that the main mode of transmission is from person to person (McIntosh, 2020). The spread of SARS-CoV-2 through respiratory droplets is considered the primary route of transmission, very similarly to the mode of transmission of the flu. When a person infected with this virus talks, sneezes or coughs, viral particles are released and transmitted with respiratory droplets. If they come into direct contact with mucous membranes of a healthy person, infection may occur. Infection can also occur if a healthy person touches their eyes, nose or mouth after touching a contaminated surface. Droplets usually do not travel more than six meters and they do not linger in the air (McIntosh, 2020). However, there is no certain evidence of airborne transmission of SARS-CoV-2 under natural conditions. A recent publication (van Doremalen et al., 2020) has described a study in which SARS-CoV-2 remained viable in experimentally generated aerosols for at least three hours, whereas some studies have detected the presence of viral RNA in ventilation systems and air samples in hospital wards with COVID-19 patients (Guo et al., 2020; Liu et al., 2020).

The WHO (2020) has no evidence to suggest that the virus can be transmitted through food. Experience from previous epidemics caused by agents similar to the coronavirus, such as the severe acute respiratory syndrome coronavirus (SARS-CoV) and the Middle East respiratory syndrome coronavirus (MERS-CoV), has also shown the absence of this possibility. There is currently no evidence to indicate that SARS-CoV-2 is any different in this regard. Although there are no scientific findings and published data on the role of food (either packed or unpacked) as a vector for this pathogen, it is possible to expect human infection from direct contact with contaminated surfaces, tools, equipment and other objects. However, the greatest risk of infection at any stage of food production comes from close contact with infected, sick people. Therefore, the application of good hygiene practices during food production and handling is the most important control measure against the occurrence of foodborne diseases (Đukić et al., 2016; Vesković and Đukić, 2017; Memiši et al., 2016).

\section{Disinfectants for use against SARS-CoV-2}

Food sanitation is a basic, yet essential element in all food manufacturing operations. Good knowledge of biological properties of potential contaminants and their "weak spots" is important for successful disinfection procedures and proper choice of disinfectants and techniques (Vesković and Djukić, 2017; Memiši et al., 2016). Different microorganisms show different degrees of resistance to disinfectants. The degree of resistance of microorganisms to the effect of disinfectants, ranging from the most resistant to the most sensitive, is shown in Schematic 1. 


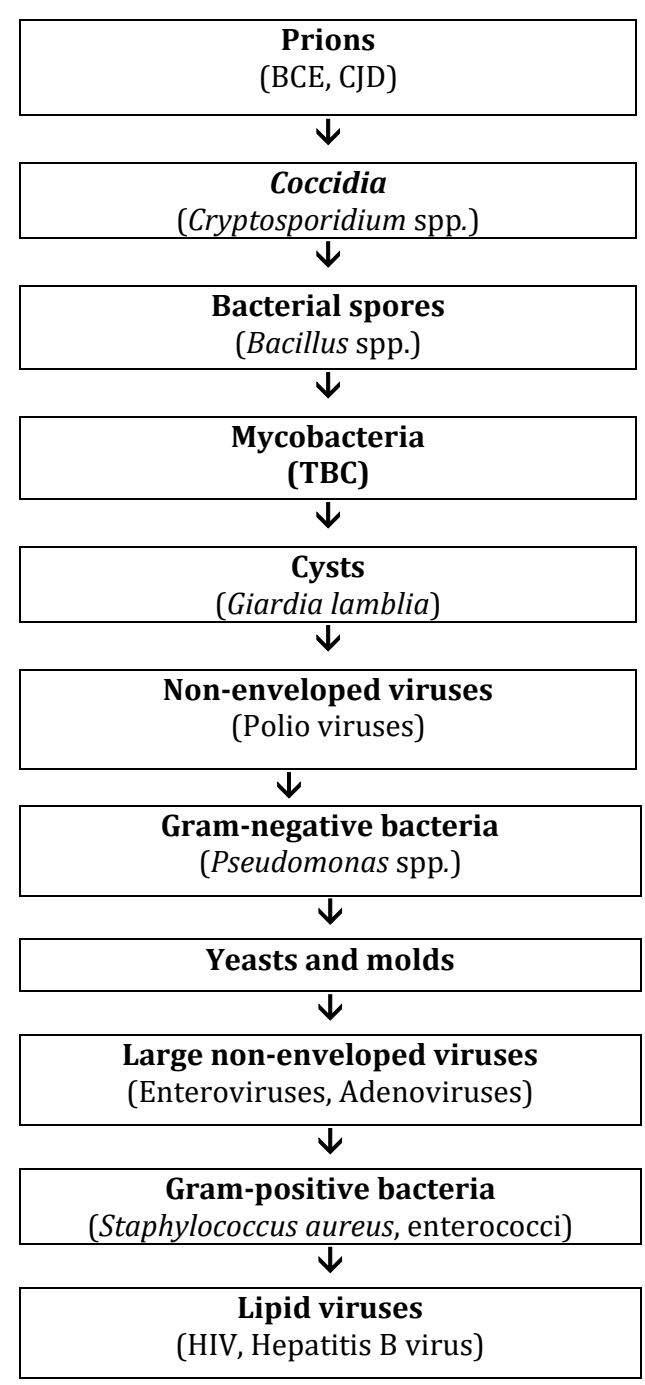

Schematic 1. Resistance of microorganisms to disinfectants - decreasing order of resistance (Vesković and Đukić, 2017)

Unfortunately, not many studies have been conducted on the selection and definition of the disinfectant of choice for use against SARS-CoV-2, but an indirect choice has been made based on the family and group of viruses it belongs to (Geller et al., 2012). As it is classified as a lipid-enveloped virus, it is not particularly resistant to the effect of disinfectants. Once the lipid envelope is damaged, the integrity of the virus is compromised, thereby neutralizing its ability to infect. The European Center for Disease Prevention and Control (ECDC, 2020), based on an analysis of the peerreviewed scientific literature, has published a list of recommended disinfectants, noting that the list is not definite and that there may be other antimicrobial compounds equally efficient. Among others, the list includes ethanol $(70 \%)$, povidone-iodine $(10 \%$ with $1 \%$ iodine) and sodium hypochlorite (0.05 and $0.1 \%)$. The U.S. Environmental Protection Agency (EPA, 2020) has also released a list of recommended disinfectants (document: List N: Disinfectants for Use against SARSCoV-2), such as hydrogen peroxide and quaternary ammonium (detergent/disinfectant).

\section{Dairy industry and COVID-19}

Definitely, the pandemic is impacting global food systems, disrupting regional agricultural value chains, and posing risks to household food security. However, dairy processors in Serbia are ramping up hygienic procedures in a bid to keep milk processing on the go, while also minimizing the risk of Covid-19.

Due to the pandemic, standard cleaning and disinfection operations in the dairy industry have been redefined and adapted to the potential causative agent through specific procedures and guidelines, and proper control measures. These activities are headed by crisis teams consisting of managing directors of dairy companies and food safety experts. Detailed explanation has been provided for the reception of raw materials, shipment of goods, and entry and movement of staff, with nonemployee entry to the dairy plant premises prohibited. The use of personal protective equipment (protective clothing, protective footwear, face masks, head coverings), hand and surface sanitation operations, and proper sanitation treatment of machines, tools, workspace, premises, means of transport etc. (Table 1) have been specified. Particular attention has been given to checking body temperature and the potential presence of respiratory symptoms for employees entering the premises. 
Table 1

Defense strategy against the coronavirus in the dairy industry

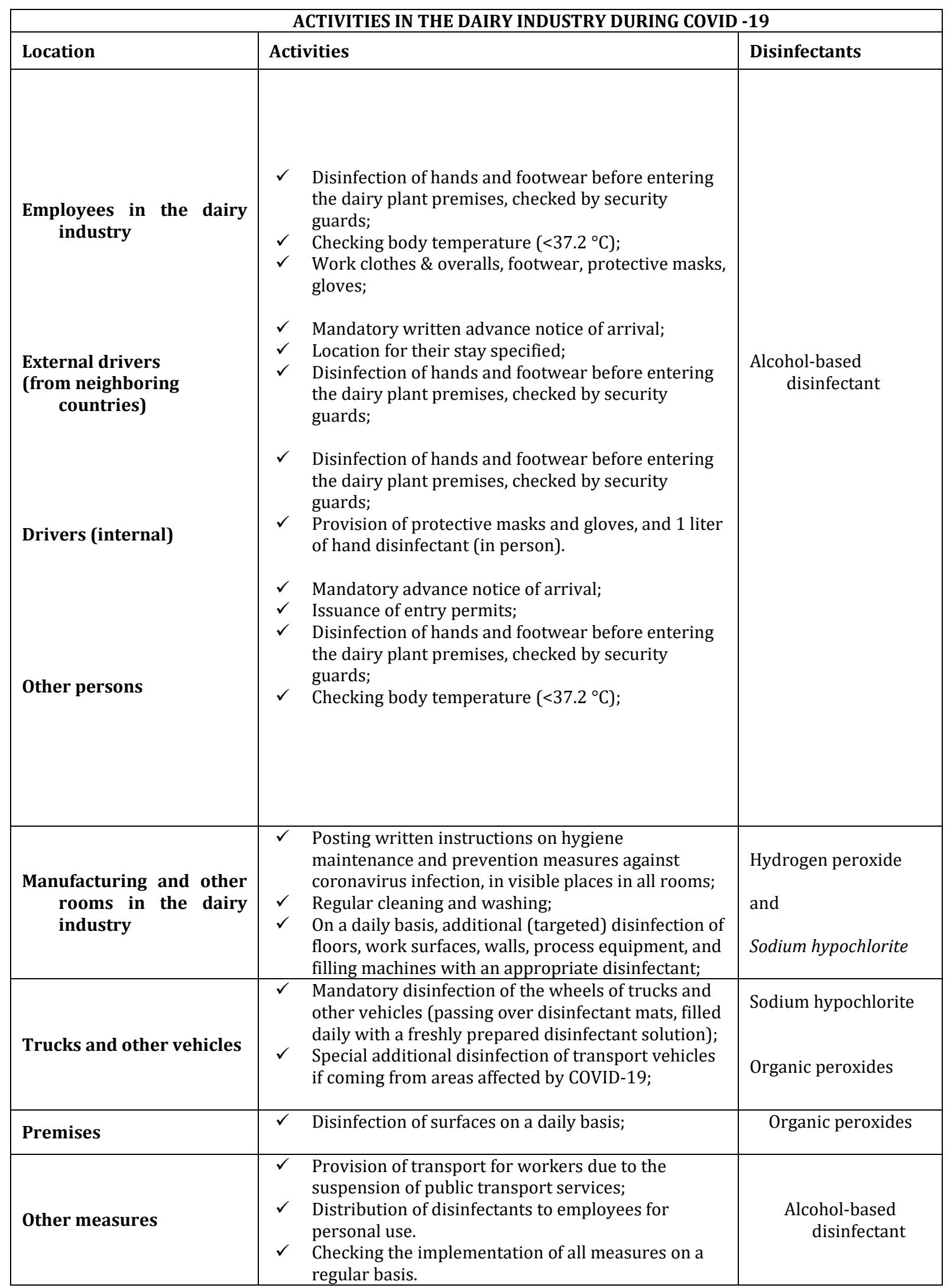

Based on the clear definition of the causative agent of the pandemic, targeted disinfection procedures involved the use of proper targeted disinfectants (Vesković and Đukić, 2017) specific to the type of surface being treated. Disinfection procedures were preceded by thorough mechanical cleaning and washing to remove impurities (of protein, lipid, mineral and physical nature) which accumulated during the daily production run. Attention should be particularly focused on the thorough removal of organic material which may serve as an ideal medium for the growth of microorganisms i.e. viruses (Lelieveld et al., 2003; 
Memiši et al., 2015). Mechanical cleaning and sanitary washing must be performed very carefully, in accordance with prescribed procedures, as part of the food safety system. This means that these operations must always be conducted following the same order and in the same manner, under both normal and pandemic circumstances. Most disinfectants can be inhibited by scraps of food products, primarily proteins, resulting in their reduced efficacy (Christian and Fryer, 2006). Moreover, microorganisms below the impurities or protected by them are not accessible by disinfectants. Therefore, cleaning and disinfection should be seen together as part of the hygiene package (Wilson, 2005).

Peroxide-based disinfectants achieve their antimicrobial effect based on irreversible oxidative changes in target microorganisms (Bakka, 1995), with no possibility of subsequent recovery through regeneration (Ronald, 2003). As peroxide is decomposed into water and oxygen, it is classified as an environmentally friendly disinfectant (Cords and Duchdala, 1993). In the dairy industry, peroxide is widely used for the disinfection of packaging used for the aseptic filling of UHT milk, sour milk drinks, fresh pasteurized milk etc. (Vesković and Đukić, 2017). As peroxide-based disinfectants have pronounced biocidal activity, they have also been used for the disinfection of work surfaces, external parts of equipment and workspace in the new coronavirus situation (EPA, 2020).

In addition, organic peroxides (peracetic acid, acetic acid), by virtue of their ability to readily release oxygen, are highly effective disinfectants having a high oxidation potential (Ronald, 2003). Following the primary reaction with proteins in the cell wall of microorganisms, peracetic acid and acetic acid, as poorly soluble organic acids, penetrate the cell, reach its interior and destroy its protein components and all enzymatic systems. All these disinfectants are effective in destroying undesirable viruses on surfaces (ECDC, 2020).

Compared with other disinfectants, sodium hypochlorite as a chlorinated inorganic disinfectant has a wide spectrum of antimicrobial activity, exhibits its activity in hard water and at low temperatures, is relatively cheap, and does not yield any active residuals. Hypochlorite is particularly effective against viruses, by destroying the protein and RNA (ECDC, 2020).

An ethanol-containing disinfectant can kill viruses within 30 seconds, by destroying the proteins and RNA (genetic material). The best results are achieved when ethanol is used at a concentration of $70 \%$ (ECDC 2020).

\section{Instead of a Conclusion}

COVID-19 is an infectious respiratory disease caused by SARS-CoV-2, pandemic in character, affecting the human population. Cases have been reported on all continents, except Antarctica, and have been steadily rising worldwide.

The WHO has no evidence to suggest that the virus can be transmitted through food. However, although there are no scientific findings and published data on the role of food as a vector for this pathogen, it is possible to expect human infection from direct contact with contaminated surfaces, tools, equipment and other objects.

The greatest risk of human/employee infection at any stage of food production and marketing comes from close contact with infected people.

The application of good hygiene and manufacturing practices is the most important control measure against this causative agent, involving the provision of adequate information and training, the protection of employees coupled with the continuous monitoring of movement and entry restrictions for people and means of transport, and proper targeted sanitation (mechanical cleaning, sanitary washing, and disinfection).

The selection and use of disinfectants, based on scientific findings and recommendations (peroxide, ethanol, hypochlorite based compounds), ensure proper protection of people and an undisturbed production cycle in the food industry in general, and in the dairy industry in particular.

\section{Acknowledgment}

This study was supported by Project Ref. No. III 46009 and Contract Ref. No. 453-03-68/2020$14 / 200050$, both funded by the Ministry of Education, Science, and Technological Development of the Republic of Serbia.

\section{References}

Bakka, R.L. (1995). Making the Right Choice - Cleaners. An Ecolab Inc., Food and Beverage Division Publication. St. Paul, MN.

Christian, G.K., Fryer, P.J. (2006). The effect of pulsing cleaning chemicals on the cleaning of whey protein deposits. Food and Bioproducts Processing, 84, 320-328.

Cords ,B.R., Dychdala, G.R. (1993). Sanitizers: Halogens, Surface-Active Agents, and Peroxides. In: P. M. Davidson and A. L. Branen, (eds.). Antimicrobials in Foods. Marcel Dekker, Inc., New York, NY. 36-52 p.

Đukić, D., Veskovic Moracanin, S., Milijasevic, M., Babic, J., Memisi, N., Mandic, L. (2016). Food safety and food sanitation. Journal of Hygienic Engineering and Design, 14, 25-31.

ECDC, European Centre for Disease Prevention and Control (2020). Interim guidance for environmental cleaning in nonhealthcare facilities exposed to SARS-CoV-2. ECDC: Stockholm.

ECDC, European Centre for Disease Prevention and Control https://www.ecdc.europa.eu/en/geographicaldistribution-2019-ncov-cases

EPA, Environmental Protection Agency (2020). https://www.epa.gov/pesticide-registration/list-ndisinfectants-use-against-sars-cov-2

Geller, C., Varbanov, M., Duval, R.E. (2012). Human Coronaviruses: Insights into Environmental Resistance and its Influence on the Development of New Antiseptic Strategies. Viruses, 4 (11), 3044-3068.

Gorbalenya, A.E., Baker, S.C., Baric, R.S., et al. (2020). The species Severe acute respiratory syndrome-related coronavirus: classifying 2019-nCoV and naming it SARSCoV-2. Nature Microbiology, 5(4), 536-544.

Guo, Z.D., Wang, Z.Y., Zhang, S.F., Li, X., Li ,L., Li, C., Cui, Y., Fu, R.B., Dong, Y.Z., Chi, X.Y., Zhang, M.Y., Liu, K., Cao, C., Liu, B., Zhang, K., Gao,Y.W., Lu, B., Chen, W. (2020). Aerosol and Surface Distribution of Severe Acute Respiratory Syndrome Coronavirus 2 in Hospital Wards, Wuhan, China, 2020. Emerging Infectious Diseases, 26(7): doi: 10.3201/eid2607.200885.

Huang, C., Wang, Y., Li, X., et al. (2020). Clinical features of patients infected with 2019 novel coronavirus in Wuhan, China. The Lancet, 395 (10223), 497-506. 
Korona virus, COVID-19, https://covid19.rs/

Lelieveld, H.L.M., Mostert, M.A., Holah, J., White, B. (2003). Cleaning and disinfection, in Lelieveld H.L.M. (Ed.) Hygiene in Food Processing - Overview. Cambridge, Woodhead, 235-278.

Liu, Y., Ning, Z., Chen, Y., Guo, M., Liu, Y., Gali, N.K., Sun, L., Duan, Y., Cai, J., Westerdahl, D., Liu, X., Xu, K., Ho, K.F., Kan, H., Fu, Q., Lan, K. (2020). Aerodynamic analysis of SARSCoV-2 in two Wuhan hospitals. Nature 2020 Apr 27. DOI: 10.1038/s41586-020-2271-3

McIntosh, K. (2020). Coronavirus disease 2019 (COVID-19): Epidemiology, virology, clinical features, diagnosis, and prevention.

UptoDate.

https://www.uptodate.com/contents/coronavirusdisease-2019-covid-19-epidemiology-virology-clinicalfeatures-diagnosis-and-prevention\#H3392906512

Memiši, N., Vesković, S., Milijašević, M. (2015). Sanitacija pogona industrije mleka i mesa. Monografija. Izdavač: Institut za prehrambene tehnologije, Novi Sad.

Ronald, H.S. (2003). Basic Elements of Equipment Cleaning and Sanitizing in Food Processing and Handling Operations. Original publication date July 1997. Revised March 2009. Reviewed November 2018. Visit the EDIS website at https://edis.ifas.ufl.edu
Van Doremalen, N., Bushmaker, T., Morris D.H., et al. (2020). Aerosol and Surface Stability of SARS-CoV-2 as Compared with SARS-CoV-1. The New England Journal of Medicine, 382, 1564-1567.

Vesković, S., Đukić, D. (2017). Sanitarna mikrobiologija, Izdavač: Agronomski fakultet Čačak.

WHO, World Health Organization (2020): Corona-virus disease (COVID-19) outbreak (https://www.who.int).

Wilson, D.I. (2005). Challenges in cleaning: recent developments and future prospects. Heat Transfer Engineering, 26(1), 51-59.

Zhou, P., Yang, X.L., Wang, X.G., Hu, B., Zhang, L., Zhang, W., Si, H.R., Zhu, Y., Li, B., Huang, C.L., Chen, H.D., Chen, J., Luo, Y., Guo, H., Jiang, R.D., Liu, M.Q., Chen, Y., Shen, X.R., Wang, X., Zheng, X.S., Zhao, K., Chen, Q.J., Deng, F., Liu, L.L., Yan, B., Zhan, F.X., Wang, Y.Y., Xiao, G.F., Shi, Z.L. (2020). A pneumonia outbreak associated with a new coronavirus of probable bat origin. Nature, 579(7798), 270-273.

Zhu, N., Zhang, D., Wang, W., Li, X1, Yang, B., Song, J., Zhao, X., Huang, B., Shi, W., Lu, R., Niu, P., Zhan, F., Ma, X., Wang, D., Xu, W., Wu, G., Gao, G.F., Tan, W. (2020). A novel coronavirus from patients with pneumonia in China, 2019. The New England Journal of Medicine, 382, 727-733. 